\title{
Pengaruh Daya Listrik Oven Gelombang Mikro terhadap Pemecahan Emulsi Minyak Mentah Cepu
}

\author{
Wasir Nuri \\ Teknik Kimia, FTI, UPN “Veteran” Yogyakarta \\ Telp/HP/Fax dan Email : (0274)486889/081578702091/486889/wasirnuri_fti@yahoo.co.id
}

\begin{abstract}
Abstrak
Uap air yang di injeksi ke dalam sumur minyak akan membentuk emulsi antara minyak mentah dengan air. Emulsi tersebut harus dipecah menjadi fase minyak dan air supaya tidak mengganggu proses pengolahan minyak di unit refinery. Stabilitas emulsi dipengaruhi oleh $\mathrm{pH}$, salinitas air, temperatur serta konsentrasi kandungan aspalten, resin dan wax. Penelitian ini bertujuan mencari efektifitas pemecahan emulsi menggunakan radiasi gelombang mikro dengan variasi daya listrik dibandingkan dengan menggunakan oven biasa. Penelitian dilakukan dengan membuat emulsi minyak mentah-air dengan salinitas air sebesar 20 permil. Emulsi tersebut kemudian dikenakan radiasi gelombang mikro di dalam oven microwave dengan daya listrik divariasi mulai 54 sampai 432 Watt. Pemecahan emulsi menggunakan gelombang mikro lebih efektif disbanding pemecahan menggunakan oven biasa. Hasil penelitian menunjukan bahwa peningkatan daya listrik akan menghasilkan persentase pemecahan emulsi semakin besar dan cepat. Pemecahan emulsi yang dibentuk dari air yang salinitasnya 20 permil menggunakan oven gelombang mikro pada daya listrik 432 Watt emulsi terpisah paling cepat dengan persentese pemecahan mencapai $100 \%$ dalam waktu 5 menit, sedangkan dengan daya 54 Watt emulsi pecah dalam 19 menit Sementara menggunakan oven biasa untuk memecah emulsi sebesar $100 \%$ diperlukan waktu 40 menit. Hasil tersebut menunjukkan bahwa pemecahan emulsi menggunakan gelombang mikro lebih efektif dibandingkan menggunakan oven biasa. Demulsifikasi menggunakan gelombang mikro pemecahanemulsi karena putaran molekul polar dan panas, sedangkan demulsifikasi dengan oven biasa pemecahan emulsi karena panas saja.
\end{abstract}

Kata kunci : Pemecahan, emulsi, minyak mentah, gelombang mikro

\begin{abstract}
Steam which injected to the oil well form a water in oil emulsion (W/O), emulsion must be broke to oil and water phase because disturb oil processing in the refinery unit. The emulsion stability depends on $\mathrm{pH}$, water salinity, temperature and asphaltene, resin and wax content. This research are to find breaking effectiveness emulsion crude oil from Cepu and compare with usual oven. In this research water crude oil emulsion made from Cepu oil well with water salinity 20 ppt. Further the emulsion is affected using microwave radiation from microwave apparatus with variation electric power from 54 to 432 Watts. Emulsion breaking with microwave more effectiv considered with effects use conventional oven. Research showed that increasing electrical power caused produce percentage emulsion breaking increase and faster. Demulsification emulsion formed water salinity 20 ppt. in microwave oven with electrical power 432 Watt is the fastest breaking with broke reach 100 percents in five minutes. While demulsification with electrical power 54 Watt the longest breaking, during nineteen minutes break 100 percents. While using conventional oven needs 40 minutes for breaking 100 percents. This results show that emulsion breaking use microwave process more effects consider with use conventional oven. microwave oven Emulsion breaking by rotated polar molecule and heat while usual oven emulsion breaking by heat only.
\end{abstract}

Keyward : Breaking, emulsion, crude oil, microwave.

\section{Pendahuluan}

Minyak mentah keluar dari perut bumi adakalanya yang harus dibantu dengan diinjeksi uap air, diinjeksi uap diperlukan karena tekanan perut bumi tidak cukup kuat untuk menekan minyak mentah keluar dari sumur minyak. Minyak mentah dan uap air keluar melalui pipa dengan turbulensi tinggi sehingga sebagian minyak mentah dan uap air membentuk emulsi minyak-air. Emulsi juga terjadi karena pencucian garam-garam yang terdapat di dalam minyak mentah. Garam-garam tersebut menyebekan emulsi lebih stabil (Kokal, 2005). 
Emulsi minyak-air menambah beban panas di reboiler, menambah daya pompa pada transportasi (pemimpaan) minyak mentah dan menurunkan nilai panas bakar minyak. Oleh karena itu emulsi harus dipecah dan air dipisahkan dari dalam minyak mentah. Penelitian ini bertujuan untuk mencari pengaruh daya listrik oven microwave terhadap pemecahan emulsi minyak mentah dari Cepu dan membandingkan effektifitas pemecahan emulsi menggunakan gelombang mikro terhadap pemanasan menggunakan oven biasa.

Metode gelombang mikro dapat digunakan sebagai salah satu alternatif metode pemecahan emulsi di unit explorasi beserta besar daya yang efektif.

\section{Emulsi}

Emulsi adalah gabungan dua atau lebih komponen yang tidak saling melarutkan dengan salah satu cairan terdispersi di dalam cairan lainya. Emulsi dapat berbentuk $\mathrm{O} / \mathrm{W}$ atau $\mathrm{W} / \mathrm{O}$ tergantung dari rasio minyak terhadap air, konsentrasi elektrolit, jenis surfaktan, temperatur dan sebagainya. Surfaktan ionic dengan HLB rendah diperkirakan membentuk W/O. (Binks, 1998).

Emulsi di dalam minyak mentah menjadi persoalan besar pada proses produksi minyak. Emulsi tersebut sukar dipisahkan dan akan menambah beban panas serta mengganggu proses fraksinasi minyak mentah, oleh karena itu emulsi harus dipecah menjadi fase air dan minyak (Sjoblom, et.al.,1994).

Emulsi minyak mentah dapat dipecah dengan cara fisika, kimia atau listrik (Kokal, et.al., 2005). Pemecahan emulsi secara listrik dicoba menggunakan gelombang mikro dan dengan ditambah garam anorganik menunjukan hasil yang lebih efektif dan efisiensi mencapai $100 \%$ dalam waktu yang sangat pendek (Xia, et. al., 2004). Abdurrahman (et.al., 2006) memecah emulsi minyak mentah-air pada perbandingan50:50 sampai 20:80\% menggunakan gelombang mikro pada frequensi 2,450 MHz. memerluakan waktu 20 sampai 180 detik dan temperatur naik secara linier seiring dengan berkurangnya air.

Percobaan membandingkan demulsifikasi emulsi minyak mentah-air dengan perbandingan 30:50 sampai dengan 70:50, pada demulsifikasi menggunakan pemanasan konvensional diperlukan waktu 5 sampai 60 menit sedangkan pemanasan dengan gelombang mikro diperlukan waktu 30 detik sampai 4 menit (Nour, et.al., 2006). Emulsi minyak mentah-air dibuat dari campuran air dan minyak mentah dengan perbandingan $50 \%$ berbanding $50 \%$ volum diaduk dengan kecepatan 1000 rpm selama 2 menit (Sjoblom, et.al.,1994).

Selama ini emulsi minyak mentah-air menjadi persoalan pada proses produksi minyak. Mekanisme dan kestabilan emulsi menjadi factor penting terhadap biaya dan pencemaran lingkungan (Aske, et. al., 2002)

Stabilitas emulsi minyak-air ditentukan oleh beberapa parameter antara lain konsentrasi garam dari 0 - 5,5 \%, pencampuran $800-1600 \mathrm{rpm}$, konsentrasi air $10-80 \%$ dan temperatur. (Nour, et. al., 2006). Hidrokarbon rantai panjang akan membentuk emulsi yang lebih stabil dari pada rantai pendek dan larutan elektrolit akan menambah kestabilan emulsi minyak-air (Binks, 1998). Aspalten merupakan zat penstabil emulsi minyak-air bilamana konsentrasinya lebih dari $500 \mathrm{ppm}$. Aspalten beraksi sebagai zat aktiv permukaan yang akan menurunkan tegangan muka molekul minyak dan air (Borges, et. al. 2009).

Analisis bahan baku ditunjukkan pada Tabel 1.

Tabel 1 Emulsifier minyak mentah Cepu

\begin{tabular}{lc}
\hline Komponen & Berat (\%) \\
\hline Aspalten & 2,002 \\
Resin & 5,65 \\
Wax & 3,939 \\
\hline & (Nuri W., 2009)
\end{tabular}

Emulsi minyak mentah-air yang terdapat di dalam minyak mentah merupakan mikro emulsi. Dalam membuat simulasi emulsi agar mendekati dengan emulsi yang terdapat di dalam minyak mentah maka emulsi dibuat dari campuran minyak mentah dan air dengan perbandingan volum $50 \%$ dibanding $50 \%$ dan diaduk dengan kecepatan putar 1400 rpm selama 5 menit.

Uji stabilitas emulsi menunjukkan bahwa emulsi minyak mentah dari Cepu dan air dengan salinitas mulai nol sampai 20 permil sangat stabil, dalam waktu satu tahun belum terjadi pemisahan air. Emulsi berbentuk pasta dan mendekati padat, selama suhu emulsi tidak lebih dari $35^{\circ} \mathrm{C}$ emulsi tidak akan terurai menjadi minyak dan air. Hal in disebabkan minyak mentah mengandung aspalten, resin dan wax, ketiganya merupakan emulsifier alam dengan kandungan aspalten lebih dari 500 ppm, perbandingan air terhadap minyak masuk dalam range stabil dan minyak mentah merupakan hidrokarbon rantai panjang dengan ditandai cairan kental serta titik didih lebih dari $100^{\circ} \mathrm{C}$ (Nuri W., 2010).

\section{Minyak Mentah}

Minyak mentah terdiri dari campuran komplek beberapa macam hidrokarbon molekul berat dan senyawa organik lainnya. Kandungan hidrokarbon dalam campuran bervariasi dari $50 \%$ sampai lebih dari $97 \%$ minyak berat (Norman, 2001). Minyak mentah mengandung partikel koloid, aspalten, agregat resin yang terdispersi di dalam larutan bercampur dengan minyak jenis alipatik atau aromatik alam (Aske, et. al., 2002). 


\section{Demulsifikasi}

Demulsifikasi adalah pemecahan emulsi menjadi fase-fase penyusun, dalam hal ini memecah emulsi minyak mentah menjadi fase minyak dan fase air. Stabilitas emulsi minyak mentah-air dicapai karena pembentukan lapisan antarmuka partikel air dan minyak mentah. Penurun stabilitas dan pemecahan emulsi berhubungan sangat erat dengan mengenyahkan lapisan antarmuka. Untuk memecah emulsi menjadi minyak dan air maka lapisan antar muka harus dihancurkan selanjutnya butiran-butiran air akan bergabung.

Ada dua tahapan demulsifikasi . Tahap pertama adalah pemecahan emulsi menjadi fase minyak dan air, dan tahap kedua adalah penggabungan menjadi satu fase penyusun (Kokal, 2005).

Faktor-faktor yang berpengaruh terhadap kecepatan pemecahan emulsi antara lain: kenaikan temperatur, penurunan agitsi atau pemotongan, kenaikan waktu tinggal, pengenyahan padatan, pengendalian zat pemicu emulsi (Kokal, 2005).

Demulsifikasi dapat dilakukan dan disempurnakan dengan satu metode atau kombinasi dari metode- metode berikut:

Metode fisis dapat dilakukan dengan bermacam cara yaitu: Pemanasan, penurunan kecepatan aliran, merubah karakter fisik dari emulsi (Kokal, 2005).

Metode kimia paling umum digunakan untuk memecah emulsi yaitu dengan menambahkan zat kimia yang disebut demulsifier. Zat kimia tersebut dirancang untuk menetralkan pengaruh pemicu pengemulsi yang menstabilkan emulsi. Pada pemakaian metode kimia yang perlu diperhatikan adalah : pemilihan dan jumlah zat kimia yang cocok, pencampuran, $\mathrm{pH}$, kecukupan waktu dan suhu (Kokal, 2005).

Metode listrik dilakukan menggunakan medan listrik. (Aske, et. al., 2002). Medan listrik akan mengganggu film antar muka dengan cara penataan kembali molekul-molekul polar. Dengan cara tersebut ikatan film menjadi lemah (Kokal, 2005). Gelombang mikro dapat digunakan untuk memecah sejumlah emulsi dari hidrokarbon (Halek, et. al., 2003).

\section{Gelombang mikro}

Menurut Maxwell sebuah medan magnetik yang berubah terhadap waktu bertindak sebagai sumber medan listrik dan sebuah medan listrik yang berubah terhadap waktu dapat bertindak sebagai sumber medan magnet. Medan listrik dan medan magnet ini dapat saling menopang membentuk sebuah gelombang elektromagnetik yang merambat melalui ruang.

Menurut Maxwell jika sebuah muatan listrik bergerak dengan kecepatan tetap maka di sekitar garis lintasan akan timbul medan magnet dan medan listrik. Medan listrik dan medan magnet bergerak tegak lurus tehadap arah perambatan dan medan listrik dan medan magnet saling tegak lurus satu dengan lainya dan bergerak ke satu arah maka gelombang tersebut merupakan gerak tranfersal (Young, 2002).

Energi yang dihasilkan gelombang mikro dapat dirumuskan sebagai berikut :

$$
\mathrm{u}=\frac{1}{2} \varepsilon_{0} E^{2}+\frac{1}{2 \mu_{0}} B^{2}
$$

dengan $u$ energi (Joule), $\varepsilon_{\mathrm{o}}$ permeabilitas medan listrik, $\mu_{0}$ permeabilitas medan magnet, E medan listrik (Volt $/ \mathrm{m})$ dan B medan magnet (Tisla).

Hubungan medan magnet terhadap medan listrik dinyatakan dengan persamaan

$$
\mathrm{B}=\mathrm{E} / \mathrm{c}=\sqrt{\varepsilon_{0} \mu_{0} E}
$$

sehingga

$$
u=\varepsilon_{0} E^{2}
$$

Aliran energi persatuan waktu setiap satuan luas (S)

$$
\begin{aligned}
& \mathrm{S}=\varepsilon_{0} c E^{2} \\
& \mathrm{~S}=\frac{E B}{\mu_{0}}
\end{aligned}
$$

Gelombang elektro magnetik merupakan gelombang sinusoida sehingga besar energinya setiap waktu tidak sama, energy rata-ratanya adalah:

$$
\begin{aligned}
& \mathrm{S}_{\text {rata-rata }}=\frac{E_{\max } B_{\max }}{2 \mu_{0}} \\
& \mathrm{~S}_{\text {rata-rata }}=\mathrm{I}
\end{aligned}
$$

dimana I adalah arus listrik dalam Ampere (Young, 2002).

Gelombang elektromegnetik berdiri adalah gelombang sinusoidal dimana gelombang medan magnet berberda fase $90^{\circ}$ terhadap gelombang medan listrik.Vektor medan listrik, vector medan magnet dan arah perambatan merupakan bentuk koordinat Cartesian bergerak maju searah sumbu $\mathrm{x}$ dan berotasi melingkar pada sumbu $\mathrm{x}$ tersebut seperti gerak sekrup, (Haznadar, 2000).

Alat memasak gelombang mikro menggunakan gelombang elektromegnetik berdiri. Panjang gelombang mikro sebesar $12,2 \mathrm{~cm}$ atau jarak antara bidang simpul sebesar $6,1 \mathrm{~cm}$ (Young, 2003).

Nour et. al., (2006) melakukan penelitian potensi teknik gelombang mikro pada demulsifikasi emulsi minyak mentah-air. Dari percobaanya diperoleh hasil bahwa dengan cara penyinaran gelombang mikro dapat mempercepat demulsifikasi emulsi minyak mentah-air dibandingkan dengan cara konvensional. Di sebuah laboratorium dan test lapangan telah didemostrasikan bahwa radiasi gelombang mikro dapat memecah emulsi airminyak-padatan. Demulsifikasi menggunakan radiasi gelombang mikro menunjukan pemisahan 
minyak dari air lebih cepat dibandingkan dengan cara konvensional (Fang, et. al., 1988).

Menurut (Halek, et. al., 2003) gelombang mikro dapat digunakan untuk mengolah sejumlah kontaminan pada emulsi hidrokarbon. Demulsifikasi menggunakan gelombang mikro pemisahanya tergantung pada frequensi dan kekuatan gelombang mikro.

Energi gelombang mikro dapat memperlemah ikatan antara molekul hidrokarbon dengan molekul air sehingga dengan pancaran gelombang mikro yang sesuai dapat menyebabkan ikatan molekul hidrokarbon dengan molekul air menjadi pecah selanjutnya hidrokarbon akan terpisah dengan air dalam waktu 4 sampai 12 jam (Halek, et. al., 2004).

Air merupakan molekul polar sehingga muatan pada kutub-kutubnya akan tarik menarik dengan medan listrik yang bermuatan berlawan jenis pada gelombang elektro magnetik. Gelombang elektro magnetik dari alat pemasak mikro bergerak berotasi menyebabkan molekul air ikut berputar. Satu putaran memakan waktu satu pereode panjang gelombang. Oven gelombang mikro memancarkan gelombang mikro biasanya pada frekuensi 2,450 $\underline{\mathrm{MHz}}$ dengan panjang gelombang $12,24 \mathrm{~cm}$, dengan demikian gelombang mikro setiap satu detik berotasi sebanyak 2.450 ribu kali. Putaran sebanyak itu menyebabkan molekul air berputar sebanyak 2.450 ribu kali. Molekul minyak atau molekul bukan jenis polar tidak ikut berputar. Molekul air berputar sangat cepat sedangkan molekul minyak diam akibatnya ikatan molekul air-minyak pecah dan gesekan antara air dengan minyak menimbulkan friksi sehingga timbul panas, panas tersebut membantu demulsifikasi (Lee, 2005). Demulsifikasi menggunakan gelombang mikro pemisahanya tergantung pada frequensi dan kekuatan atau daya gelombang mikro (Halek, et. al., 2003).

\section{Oven Gelombang mikro}

Oven gelombang mikro adalah sebuah peralatan dapur yang menggunakan radiasi gelombang mikro untuk memasak atau memanaskan makanan. Alat pemasak gelombang mikro memakai gelombang elektro magnetik berdiri dengan bidang gelombang medan magnet dan medan listrik bergerak maju secara tranfersal dan berotasi seperti sekru bergerak maju sambil berputar.

Bagian utama oven gelombang mikro pada umumnya sebuah magnetron, rangkaian pengendali atau pengatur gelombang atau waveguide dan ruang pemasak.

Molekul di dalam makanan sebagian besar bersifat polar artinya mereka memiliki sebuah muatan positif pada satu sisi dan sebuah muatan negatif di sisi lainnya oleh karena itu mereka akan berputar pada saat molekul menata dirinya dengan medan listrik yang berubah-ubah serta diinduksi oleh pancaran gelombang mikro. Gerakan molekuler inilah yang menciptakan panas (Lee, 2000).
Air adalah molekul polar artinya ada kutub yang bermuatan negative dan sisi lainya bermuatan positiv seperti jarum kompas. Jika salah satu kutub atau kedua kutub berada pada medan listrik sejenis yang berasal dari gelombang mikro maka akan terjadi gaya totak menolak menyebabkan molekul air akan berputar. Karena rotasi tersebut akan terjadi gesekan dan akan timbul panas (Lee, 2000).

Penelitian pemecahan emulsi minyak mentahair menunjukkan bahwa menggunakan gelombang mikro pemecahan emululsi lebih cepat dan efektiv dibandingkan pemecahan menggunakan oven biasa. Pada oven gelombang mikro untuk memecah emulsi sampai $100 \%$ diperlukan waktu 15 menit, sedangkan menggunakan oven biasa diperlukan waktu 40 menit (Nuri, W., 2009).

\section{Metode Penelitian}

\section{Bahan dan Alat}

Bahan baku yang digunakan pada penelitian ini adalah crude-oil yang berasal dari sumur minyak Cepu. Penelitian di sini menggunakan alat Oven Microwave dengan merk SHARP model R-108 SE, frequensi 2,450 MHz, daya input 960 Watt, daya output 600 Watt, power suply AC 220 Volt.

\section{Cara Penelitian}

Garis besar penelitian terdiri dari 3 tahap yaitu : Tahap satu: Menyiapkan bahan penelitian dengan cara mencampur minyak mentah dengan air di dalam gelas Becker ukuran $100 \mathrm{ml}$ dan diaduk dengan kecepatan $1400 \mathrm{rpm}$ selama 5 menit. Tahap dua: Demulsifiksi emulsi minyak-air menggunakan oven gelombang mikro. Pada percobaan ini $10 \mathrm{ml}$ emulsi pada salinitas $20 \%$ dimasukkan ke dalam tabung reaksi $20 \mathrm{ml}$ kemudian dipanasi menggunakan oven gelombang mikro pada daya 54 Watt. Minyak mentah dan air yang terpisah diukur volum dan suhunya setiap 5 menit sampai 40 menit atau emulsi pecah 100 persen. Demulsifikasi diulangi menggunakan daya listrik oven 110, 168, 330 dan 432 Watt. Pada tahap ini akan diperoleh daya listrik dan suhu yang menghasilkan pemecahan emulsi paling banyak. Tahap tiga: Membandingkan demulsifiksi emulsi menggunakan oven gelombang mikro terhadap oven biasa pada suhu yang sesuai dengan tahap dua. Pada tahap ini $10 \mathrm{ml}$ emulsi dengan salinitas 20 permil dimasuklkan ke dalam tabung reaksi, tabung reaksi dan emulsi dimasukkan ke dalam oven biasa pada suhu yang sesuai dengan percobaan pada tahap dua. Minyak mentah dan air yang terpisah diukur volumnya setiap 30 menit sampai 24 jam. Pada tahap ini akan dihasilkan demulsifikasi mana yang lebih cepat dan efektif. Diagram tahapan penelitian dapat dilihat pada Gambar 1.

\section{Analisis Data Percobaan.}


Pengolahan data hasil penelitian pada tahap 1, 2, dan 3 menggunakan metode deskriptif.

Tahap 2: Analisis data percobaan dengan bantuan tabel dan grafik pengaruh daya listrik terhadap persentase pemecahan emulsi sampai pada waktu tertentu. Dari grafik atau tabel dapat diperoleh salinitas yang memberikan persentase pemecahan emulsi terbanyak Tahap 3 membandingkan data percobaan antara demulsifikasi menggunakan oven gelombang mikro terhadap oven biasa pada suhu yang sesuai dengan pada tahap dua diamati saat emulsi terurai menjadi fase minyak dan air. Dari tahap ini akan diperoleh demulsifikasi yang mana yang efektif dan cepat.

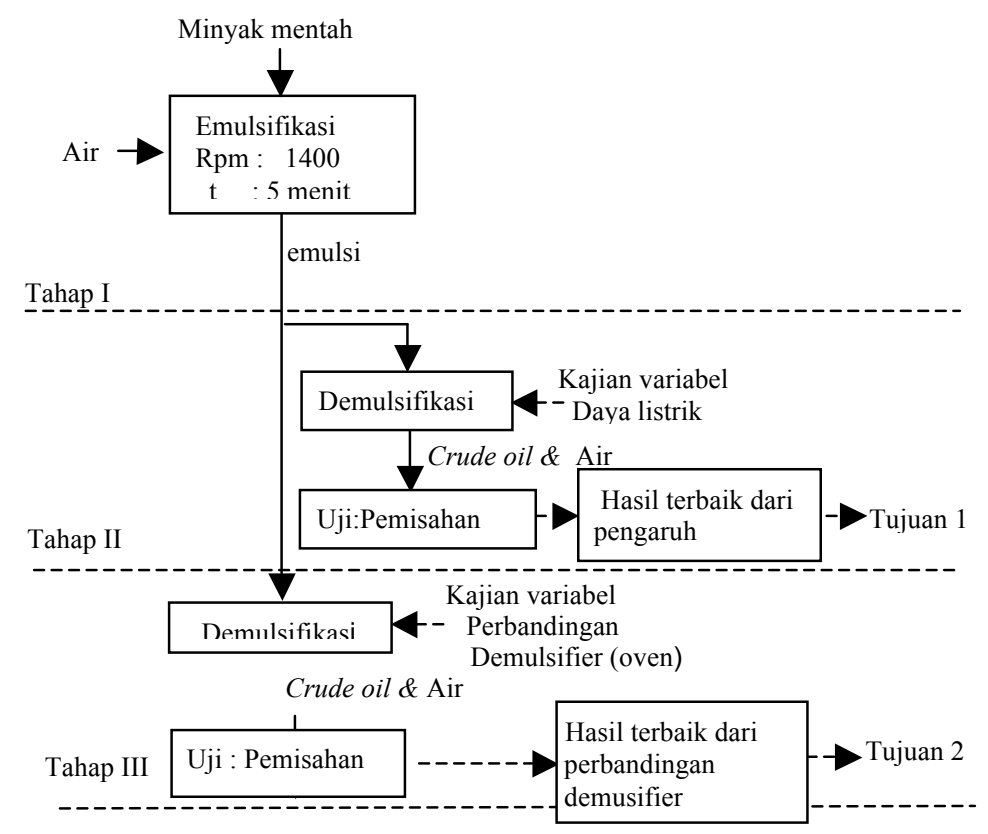

Gambar 1. Diagram alir tahapan penelitian

\section{Hasil dan Pembahasan}

\section{Pengaruh Daya Listrik}

Hasil percobaan pengaruh daya listrik terhadap presentase pemecahan emulsi dengan salinitas air 20 permil dalam sampai waktu 40 menit ditunjukkan pada Gambar 2.



Gambar 2 Pengaruh daya terhadap Persentase air terpisah

Gambar 2. menunjukan bahwa semakin besar daya listrik pemecahan emulsi semakin cepat. Sebagai contoh pemecahan emulsi dengan daya listrik 54 Watt dalam waktu 40 menit air yang terpisah sebesar $19 \%$, sedangkan dengan daya listrik 432 Watt air yang terpisah mencapai $100 \%$ dalam waktu 10 menit. Besarnya tingkat pemecahan emulsi ini disebabkan oleh daya listrik. Daya listrik yang semakin besar mengakibatkan daya putar gelombang elektro magnetik berdiri semakin kuat. Air dan garam yang merupakan senyawa polar akan ikut berputar jika mendapat pancaran gelombang elektro magnetik berdiri sedangkan minyak tidak berputar oleh sebab itu emulsi yang diputar dengan kekuatan putar yang lebik kuat akan lebih cepat pecah. Kekuatan putar gelombang elektromagnetik disebabkan oleh daya listrik yang lebih besar. Disamping itu dengan daya putar yang semakin kuat tersebut akan lebih cepat timbul panas, panas akan membantu pemecahan emulsi. Pengaruh daya terhadap suhu dapat dilihat pada gambar 3 . 


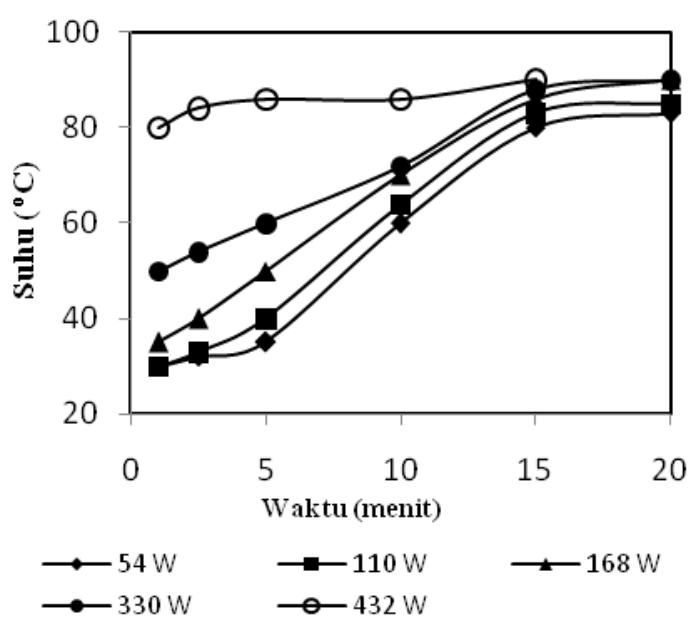

Gambar 3 Pengaruh Daya terhadap Suhu Demulsifier

\section{Perbandingan demulsifikasi}

Data perbandingan demulsifiksi antara oven Microwave terhadap oven biasa disajikan dalam bentuk grafik seperti ditunjukkan pada Gambar 3 berikut.

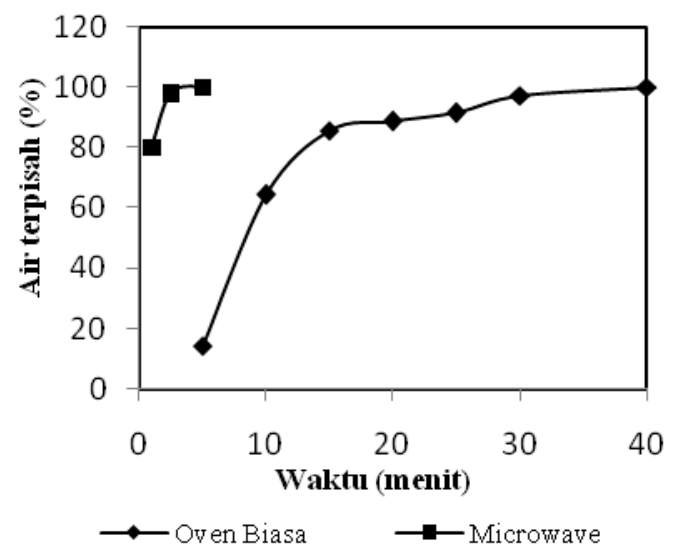

Gambar 3 Perbandingan Demulsifikasi antara microwave dengan oven biasa

Hasil perbandingan demulsifikasi terlihat bahwa demulsifikasi menggunakan oven gelombang mikro pemecahan emulsi lebih cepat. Sebagai contoh demulsifikasi menggunakan oven gelombang mikro pemecahan emulsi $100 \%$ diperlukan waktu 5 menit, sedangkan demulsifikasi menggunakan oven biasa diperlukan waktu 40 menit. Hal ini disebabkan demulsifikasi menggunakan oven gelombang mikro pemecahan emulsinya oleh putaran molekul polar dan panas yang ditimbulkan, sedangkan demulsifikasi menggunakan oven biasa pemecahan emulsinya hanya disebabkan oleh panas saja.
1. Daya listrik berpengaruh terhadap kecepatan pemecahan emulsi menggunakan pancaran gelombang mikro, semakin besar daya listrik pemecahan emulsi semakin cepat. Oven gelombang mikro dapat memecah emulsi mencapai $100 \%$ dalam 5 menit dengan daya 432 W. pada salinitas air 20 permil. Sedangkan dengan daya $54 \mathrm{~W}$ diperlukan waktu 19 menit.

2. Demulsifikasi menggunakan oven gelombang mikro lebih cepat dan efektiv dibanding demulsifikasi menggunakan oven biasa. Pada oven gelombang mikro untuk memecah emulsi $100 \%$ diperlukan waktu 5 menit, sedangkan pada oven biasa diperlukan waktu 40 menit.

\section{Daftar Pustaka}

Abdurahman, H., Nour, H., Rosli, Yunus, M., Zulkifly, J., 2006, Study on Demulsification of Water-in-Oil Emulsions Via Microwave Heating Technology,J. Applied Sci., 6, p.2060.

Aske, N, Kallevik, H. and Sjoblom, J., 2002, Water-in Crude oil emulsion stability studied by critical electric field measurements, Statoil $R \& D$ centre, pp. 2-5.

Binks, B.P., 1998, Modern Aspects of Emulsion

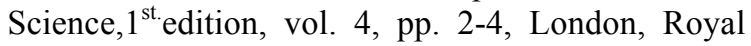
Society of Chemistry.

Borges, B., Rondon, M., Sereno, O. and Asuje, 2009, Breaking of Water-in-Crude-Oil Emulsions. 3. Influence of Salinity and Water-Oil Ratio on Demulsifier Action, Enegy Fuel, Vol. 23, p. 1569.

Fang, C. S., Bruce K. L., Chang, Peter M. C., Lai, Klaila, W. J., 1988, MICROWAVE EMUlSIFICATION, Chem. Eng. Com., Vol.73,p. 227.

Halek, J.M., Harris, P.A., Thompson, R., Ferri, R., Squires, J., 2003, Microwave Demulsification of Hydrocarbon Emulsion, United States Patent and Trademark Office (USPTO), No. 10/619,011.

Haznadar, Z. and Stih, Z. 2000, Electromagnetic field, Wave and Numerical Methods, IOS Press, p. 242.

Kokal, S., 2005, Crude Oil Emulsion : A State of the Art Review, SPE Sauci Aramco, Revec ed., pp. 5-9.

Lee, 2000, How Microwaves Work, pp.1-3, Colorado. Colorado University.

Lee, 2000, Method of treating foodstuff, U.S., Patent 2495429

Norman, J.H., 2001, Nontechnical Guide to Petroleum Geology Exploration, Drilling and Production, p. 4, $2^{\text {nd. }}$ edition, Oklahoma, Penn Well Corporation.

\section{Kesimpulan}


Nour, H., $\quad$ Abdurahman H., Yunus, M. R.; Anwaruddin, H., 2006, Water-in-Crude Oil Emulsions: Its Stabilization and Demulsification, $J$. Applied Sci., vol.7, p.19.

Nuri W., 2009, Pemecahan Emulsi Minyak Mentah Cepu Menggunakan Gelombang Mikro, Eksergi, Vol. IX, no 1, hal. 34, 39.

Sjoblom, J., Mingyuan, L., Christy A.A., Ronningsen, H. P.,1994, Water-in-crude oil
Emulsions, pp. 55-62, Bergen, Reservoir Technology,

Xia, L.X., Lu, S.W., and Cao, G.Y., 2004, SALTASSISTED MICROWAVE DEMULSIFICATION, Chem. Eng. Com., Vo.191, p. 1053.

Young, H.D. and Freedman, R.A., 2002, University Physics, pp. 464-475, $10^{\text {th. }}$ edition, California, Wesley Longman, Inc. 